\title{
Long-Term Prognosis After Revascularization Therapy in Patients with Atherothrombotic Stroke
}

\author{
Aterotrombotik Inme Geçiren Hastalarda Revaskülarizasyon Sonrası \\ Uzun Dönem Prognoz
}

Ugur UYGUNOGLU, Gulcin BENBIR, Baki GOKSAN, Birsen INCE

Istanbul University, Cerrahpasa Faculty of Medicine, Department of Neurology, Istanbul, Turkey

Corresponding Author: Ugur UYGUNOGLU / E-mail: uuggun1903@yahoo.com

\begin{abstract}
AIM: Many guidelines recommend carotid endarterectomy (CEA) in symptomatic patients with carotid stenosis of greater than $70 \%$, and carotid artery stenting (CAS) as an alternative to CEA. In our study, we evaluated the clinical characteristics of patients who underwent revascularizaton therapy.

MATERIAL and METHODS: We reviewed the files of 2369 patients with stroke followed in our cerebrovascular outpatient clinics since 1996.

RESULTS: 92 patients were treated by revascularization therapy. A total of 41 patients had CEA, 42 patients had CAS, and 9 patients had vertebral artery stenting; and 77 patients were followed-up for a mean period of 50.2+42.7 months ( 6 to 168 months). Recurrent stroke or TIA and deaths due to cerebrovascular diseases were similar between CEA and CAS patients. Myocardial infarction (including silent MI) and deaths due to cardiovascular diseases were more common in CAS group, though not significant. The deaths due to other diseases and other non-fatal complications were significantly more common in CEA patients. On the other hand, restenoses - all of which were radiological findings but asymptomatic - were more common in the CAS group.
\end{abstract}

CONCLUSION: In this study we disclosed neither morbidity nor mortality discrepancies in long term among the patients who were treated with carotid endarterectomy (CEA) and carotid artery stenting (CAS).

KEYWORDS: Carotid endarterectomy, Carotid artery stenting, Long-term prognosis

öz

AMAÇ: Birçok kılavuz karotis interna'da \%70 üstündeki stenozda ilk sırada karotis endarterektomiyi (KEA), alternatif olarak ise karotis arter stentini (KAS) önerir. Çalışmamızda, revaskülarizasyon tedavisi uygulanmış tüm hastaların klinik özelliklerini değerlendirdik.

YÖNTEM ve GEREÇLER: Serebrovasküler hastalık polikliniğimizde, 1996'dan itibaren takip ettiğimiz 2369 hastanın dosyasını taradık.

BULGULAR: Hastaların 92'si revaskülarizasyon ile tedavi edildi. 41 hastaya KEA, 42 hastaya KAS ve 9 hastaya vertebral arter stenti uygulandı. 77 hasta ortalama 50.2+42.7 ay takip edildi ( 6-168 ay arası). Tekrarlayan inme veya geçici iskemik atak ve ölümler KAS ve KEA grupları arasında benzerlik göstermekteydi. Miyokard infarktüsü ( sessiz MI da dahil) ve kardiovasküler hastalıklara bağlı ölümler KAS grubunda daha fazla olsa da istatistiksel olarak anlamlı değildi. Diğer hastalıklara bağlı ölüm ve diğer ölümcül olmayan komplikasyonlar KEA grubunda daha fazlaydı. Diğer taraftan restenoz -hepsinde radyolojik bulgu olan ama asemptomatik-KAS grubunda daha fazlaydı.

SONUÇ: Bu çalışmada, KAS ve KEA sonrası uzun dönem morbidite ve mortalite açısından her iki grup arasında farklılık bulunmadı.

ANAHTAR SÖZCÜKLER: Karotis endarterektomi, Karotis arter stent, Uzun dönem prognoz

\section{INTRODUCTION}

Despite improvements in diagnosis and management, cerebrovascular diseases are the third leading cause of death following heart diseases and cancer, and the leading cause of long-term disability (30). Stroke survivors still remain at substantial risk of developing subsequent strokes, emphasizing the importance of secondary preventive measures. Ten to thirty percent of ischemic strokes are secondary to emboli from the carotid arteries $(3,10)$. In the Framingham Heart Study population, the prevalence of $>50 \%$ carotid stenosis was $7 \%$ in women and $9 \%$ in men ranging in age from 66 to 93 years (14). In the Cardiovascular Health
Study of subjects older than 65 years of age, $7 \%$ of men and $5 \%$ of women had moderate carotid stenosis ( $50 \%$ to $74 \%$ ); and severe stenosis ( $75 \%$ to $100 \%$ ) was detected in $2.3 \%$ of men and $1.1 \%$ of women (2). The odds ratio was reported as 3.3 for patients with symptomatic stenosis compared to other stroke etiologies, and up to $26 \%$ overall risk was found in the first 2 years after the initial event in medically treated patients (24).

During the 1990s, carotid endarterectomy (CEA) was first established as the choice of treatment in carotid stenosis $(7,9,10)$, and many guidelines recommend CEA in symptomatic patients with carotid stenosis of greater than $70 \%$ or in 
asymptomatic patients with carotid stenosis of greater than $60 \%(7,8,15,16)$. Accurate assessment of the severity of arterial stenosis is, however, essential to the selection of appropriate patients for surgical or endovascular intervention. Carotid duplex ultrasonography (DUS), computed tomography angiography (CTA), and magnetic resonance angiography (MRA) can provide the information needed to guide the choice of medical, endovascular, or surgical treatment in most cases. Surgery was most effective in patients with $>70 \%$ carotid stenosis without occlusion or near-occlusion (34). When the combined outcome of fatal or disabling ipsilateral ischemic stroke, perioperative stroke, or death was considered, the benefit of surgery was evident in patients with $80 \%$ to $99 \%$ stenosis.

In the last decade, carotid artery stenting (CAS) has emerged as an alternative to CEA for the treatment of carotid artery occlusive disease, and has been endorsed by the American Heart Association/American Stroke Association guidelines as a reasonable strategy when performed by operators with established peri-procedural morbidity and mortality of $4 \%$ to $6 \%$ (class Ila) $(18,35)$. The European Society of Vascular Surgery recommends CAS instead of CEA in participants at high risk for cardiovascular disease if it is conducted in high-volume centers with documented low perioperative stroke and death rates (23). Although CAS has the advantage of being a lessinvasive procedure, potentially minimizes the risks of wound complications and cranial nerve injury, and shortens the length of hospitalization, the safety and efficacy of CAS are controversial (33).

Symptomatic occlusions of the vertebral arteries are less commonly encountered in clinical practice. In compared with CEA, operations are rarely performed in vertebral stenosis. There are no randomized trials in the management of vertebral stenosis; although some reports showed good outcomes with surgical treatment $(4,20)$, angioplasty and stenting of the vertebral vessels are technically much more feasible with favorable prognosis.

In our study, we aimed to evaluate the clinical characteristics of patients who underwent revascularization therapy, and to investigate the long-term prognosis following endarterectomy versus stenting.

\section{MATERIAL and METHODS}

In this retrospective cohort study, we reviewed the files of 2369 patients with stroke followed at our cerebrovascular outpatient clinics since 1996. A total of 2151 patients $(90.7 \%)$ had ischemic stroke, and 379 of these (17.6\%) were diagnosed as having ischemic atherothrombotic stroke due to large artery atherosclerosis according to TOAST criteria, upon a detailed clinical evaluation, physical and neurological examinations, and neuroimaging characteristics (1). The diagnosis of ischemic stroke was established by cranial computed tomography (CT) and/or magnetic resonance imaging (MRI). The diagnosis of large artery atherosclerosis was based on neuroimaging findings by carotid DUS and
CTA or MRA; and/or catheter-based contrast angiography, in which either a significant stenosis $(>50 \%)$ or occlusion was established in carotid or vertebral arteries. The potential causes of cardiogenic embolism were excluded in all patients.

The demographic data and the risk factors of 379 patients were reviewed. Risk factors included gender, age (over 45 years for male and over 55 years or premature menopause needing estrogen replacement therapy for female), smoking, alcohol intake, hypertension (systolic blood pressure $>140 \mathrm{mmHg}$ and/or diastolic blood pressure $>90 \mathrm{mmHg}$ that was recorded in medical files), antihypertensive therapy, presence of cardiac disease, the type of cardiac disease if any, dyslipidemia (blood total cholesterol $\geq 200 \mathrm{mg} / \mathrm{dl}$, triglyceride $\geq 150 \mathrm{mg} / \mathrm{dl}$, LDL cholesterol $\geq 100 \mathrm{mg} / \mathrm{dL}, \mathrm{HDL}$ cholesterol $\leq 40 \mathrm{mg} / \mathrm{dL}$ ), lipidlowering therapy, non-insulin dependent diabetes (fasting blood glucose $>140 \mathrm{mg} / \mathrm{dl}$ in two consequent measurements or blood glucose level of $>200 \mathrm{mg} / \mathrm{dl}$ after $75 \mathrm{mg}$ oral glucose tolerance test), antidiabetic therapy, history of previous cerebrovascular disease and the use of anti-thrombotic or anticoagulation therapy.

The decision of revascularization and the choice of the type of intervention were based on the recent guidelines of the era, but also on the patients' and their families' decisions $(13,27)$. We evaluated the pre- and post-Rankin values for patients who underwent revascularization therapy. In addition to other risk factors, the side of the intervention and the presence of occlusion on the opposite artery were also noted. The primary endpoints were set as recurrent transient ischemic attacks (TIA) or stroke, myocardial infarction (MI) including silent MI, peripheral vascular diseases, and deaths due to cardiovascular diseases. The emergence of diseases, and deaths due to other diseases than cardiovascular disorders were the secondary outcomes.

The statistical analyses were performed with the software (version 11.5 for Windows; SPSS, Chicago, IL). Statistical tests used in the analysis were $\mathrm{X} 2$ or Fisher's test for independent categorical variables, Student $t$ test and analysis of variance (ANOVA) for normally distributed independent numerical variables, and Mann-Whitney $U$ and Kruskal-Wallis test for not normally distributed independent numerical variables. The effects of covariates and independent variables on the development of atherothrombotic events were investigated by covariance analysis (ANCOVA) and logistic regression. A $p$ value of $\geq 0.05$ was considered statistically significant.

\section{RESULTS}

We evaluated the files of 2369 patients with stroke followed in our cerebrovascular outpatient clinics since 1996. Of these, 379 patients were diagnosed as having ischemic atherothrombotic stroke, and 92 of them (24.2\%) were treated by revascularization. The clinical characteristics of patients treated with invasive intervention and those with medical therapy are given in Table I. Men were more commonly treated with revascularization therapy $(p=0.035)$, and smoking was more common in this group of patients $(p=0.044)$. All other risk factors were similar in two groups. 
The evaluation of patients with revascularization therapy revealed that 41 patients out of 379 patients with ischemic atherothrombotic stroke received CEA (10.8\%), 42 patients had CAS (11\%), and only 9 patients had VAS (2.3\%). Table II demonstrates the characteristics of patients underwent CEA, CAS or VAS. Hyperlipidemia $(p=0.019)$ was more common in patients underwent CAS, while smoking was more common $(p=0.034)$ in patients having CEA. The history of cardiac diseases and coronary artery disease was observed more common in CEA group, and the history of previous stroke was more common in CAS patients, but these differences did not reach statistically significant level ( $p>0.05)$. The other risk factors were similar between CEA and CAS patients.

Seventy-seven patients out of 92 patients with revascularization therapy were followed-up for a mean period of $50.2 \pm 42.7$ months (varying between 6 and 168 months). The degree of stenosis was higher in patients selected for CAS, though not significant (Table III). The side of the lesion and the presence of total occlusion in contralateral carotid artery were similar in two groups. The interval between stroke and revascularization was shorter in patients with CAS in compared to patients CEA (49.1 \pm 50.3 days versus $72.1 \pm 60.6$ days respectively, $p=0.094$ ), though not statistically significant. The follow-up period was significantly longer in patients with CEA $(p=0.026)$. The preintervention Rankin scores were higher in CAS group, but not significant; while post-intervention Rankin scores or the changes in Rankin scores were similar (Table III).

Among the primary endpoints, recurrent stroke or TIA and deaths due to cerebrovascular diseases were similar between two groups. The myocardial infarction (including silent $\mathrm{MI}$ ) and deaths due to cardiovascular diseases were more common in CAS group, though not significant (Table III). The deaths due to other diseases (such as cancer, accidents...) and other non-fatal complications were significantly more common in CEA patients. On the other hand, restenoses - all of which were radiological findings but asymptomatic - were more common in CAS group (Table III).

Table I: The Clinical Characteristics of Patients

\begin{tabular}{|c|c|c|c|}
\hline Variables & $\begin{array}{l}\text { Patients with intervention } \\
\qquad(\mathrm{n}=92)\end{array}$ & $\begin{array}{l}\text { Patients with medical therapy } \\
\qquad(\mathrm{n}=287)\end{array}$ & p values \\
\hline Age (years, mean \pm s.d.) & $64.4 \pm 8.5$ & $65.8 \pm 9.7$ & 0.145 \\
\hline Gender (males/females) & $79.3 \% / 20.7 \%$ & $69 \% / 31 \%$ & 0.035 \\
\hline Hypertension & $73.9 \%$ & $79.1 \%$ & 0.184 \\
\hline Cardiac disease & $33.0 \%$ & $32.4 \%$ & 0.508 \\
\hline Coronary artery disease & $29.7 \%$ & $29.6 \%$ & 0.638 \\
\hline Atrial fibrillation & 0 & $2.4 \%$ & 0.062 \\
\hline Diabetes mellitus & $30.1 \%$ & $36.6 \%$ & 0.170 \\
\hline Hyperlipidemia & $42.4 \%$ & $40.8 \%$ & 0.437 \\
\hline Recurrent stroke & $18.5 \%$ & $22.3 \%$ & 0.267 \\
\hline Smoking & $59.3 \%$ & $47.7 \%$ & 0.044 \\
\hline Alcohol intake & $22.2 \%$ & $18.5 \%$ & 0.271 \\
\hline
\end{tabular}

Table II: The Characteristics of Patients Who Underwent CEA, CAS or VAS

\begin{tabular}{|c|c|c|c|c|}
\hline Variables & $\begin{array}{l}\text { Patients with CEA } \\
\qquad(n=41)\end{array}$ & $\begin{array}{l}\text { Patients with CAS } \\
\qquad(n=42)\end{array}$ & p values* & $\begin{array}{l}\text { Patients with VAS } \\
\qquad(n=9)\end{array}$ \\
\hline Age (years, mean \pm s.d.) & $65.0 \pm 9.4$ & $63.9 \pm 7.9$ & 0.460 & $64.1 \pm 6.8$ \\
\hline Gender (males/females) & $80.5 \% / 19.5 \%$ & $81.0 \% / 19.0 \%$ & 0.957 & $66.7 \% / 33.3 \%$ \\
\hline Hypertension & $75.6 \%$ & $71.4 \%$ & 0.668 & $77.8 \%$ \\
\hline Cardiac disease & $40.0 \%$ & $28.6 \%$ & 0.278 & $22.2 \%$ \\
\hline Coronary artery disease & $37.5 \%$ & $26.2 \%$ & 0.291 & $11.1 \%$ \\
\hline Diabetes mellitus & $27.0 \%$ & $34.2 \%$ & 0.503 & $25 \%$ \\
\hline Hyperlipidemia & $29.3 \%$ & $54.8 \%$ & 0.019 & $44.4 \%$ \\
\hline Previous stroke & $14.6 \%$ & $23.8 \%$ & 0.292 & $11.1 \%$ \\
\hline Smoking & $74.3 \%$ & $50.0 \%$ & 0.034 & $37.5 \%$ \\
\hline Alcohol intake & $25.7 \%$ & $23.7 \%$ & 0.842 & 0 \\
\hline
\end{tabular}

* $p$ values - between patients underwent CEA and CAS. 
Table III: The Comparison of Vascular Status and Prognosis in Patients with Intervention

\begin{tabular}{|c|c|c|c|c|c|}
\hline \multicolumn{2}{|l|}{ Variables } & $\begin{array}{l}\text { Patients with CEA } \\
\qquad(n=41)\end{array}$ & $\begin{array}{l}\text { Patients with CAS } \\
\qquad(n=42)\end{array}$ & p values & $\begin{array}{l}\text { Patients with VAS } \\
\qquad(\mathrm{n}=9)\end{array}$ \\
\hline \multicolumn{2}{|c|}{ Degree of stenosis (\%) } & $65.0 \pm 9.4$ & $85.4 \pm 10.5$ & 0.816 & $89.6 \pm 12.2$ \\
\hline \multicolumn{2}{|c|}{$\begin{array}{l}\text { Side } \\
\text { Right } \\
\text { Left } \\
\text { Bilateral }\end{array}$} & $\begin{array}{l}37.5 \% \\
43.8 \% \\
18.8 \%\end{array}$ & $\begin{array}{r}45.7 \% \\
48.6 \% \\
5.7 \%\end{array}$ & 0.252 & $\begin{array}{l}22.2 \% \\
33.3 \% \\
44.4 \%\end{array}$ \\
\hline \multicolumn{2}{|c|}{ Total occlusion in contralateral artery } & $10.7 \%$ & $24.2 \%$ & 0.174 & $22.2 \%$ \\
\hline \multicolumn{2}{|c|}{$\begin{array}{l}\text { Interval between stroke and intervention } \\
\text { (days) }\end{array}$} & $72.1 \pm 60.6$ & $49.1 \pm 50.3$ & 0.094 & $26.6 \pm 17.7$ \\
\hline \multicolumn{2}{|c|}{ Pre-intervention Rankin scores } & $1.78 \pm 1.64$ & $2.25 \pm 1.61$ & 0.215 & $2.22 \pm 2.04$ \\
\hline \multicolumn{2}{|c|}{ Post-intervention Rankin scores } & $1.93 \pm 1.88$ & $2.08 \pm 1.54$ & 0.527 & $1.66 \pm 1.58$ \\
\hline \multicolumn{2}{|c|}{ Follow-up (months) } & $63.3 \pm 52.2$ & $34.2 \pm 29.8$ & 0.026 & $26.7 \pm 31.3$ \\
\hline $\begin{array}{l}\text { Change in } \\
\text { Rankin } \\
\text { scores }\end{array}$ & $\begin{array}{l}\text { Increased } \\
\text { Decreased } \\
\text { No change }\end{array}$ & $\begin{array}{r}9.4 \% \\
3.1 \% \\
87.5 \%\end{array}$ & $\begin{array}{c}0 \\
8.6 \% \\
91.4 \%\end{array}$ & 0.531 & $\begin{array}{c}0 \\
22.2 \% \\
77.8 \%\end{array}$ \\
\hline \multicolumn{2}{|c|}{ Recurrent stroke / TIA } & $7.3 \%$ & $7.1 \%$ & 0.842 & $11.1 \%$ \\
\hline \multicolumn{2}{|c|}{ Deaths due to cerebrovascular diseases } & $2.4 \%$ & 0 & 0.184 & 0 \\
\hline \multicolumn{2}{|c|}{ Myocardial infarction } & $7.3 \%$ & $11.9 \%$ & 0.068 & $11.1 \%$ \\
\hline \multicolumn{2}{|c|}{ Deaths due to cardiac diseases } & $2.4 \%$ & $4.7 \%$ & 0.278 & 0 \\
\hline \multicolumn{2}{|c|}{ Deaths due to other diseases } & $12.2 \%$ & $7.1 \%$ & 0.036 & 0 \\
\hline \multicolumn{2}{|l|}{ Restenosis } & 0 & $4.7 \%$ & 0.014 & 0 \\
\hline \multicolumn{2}{|c|}{$\begin{array}{l}\text { Emergence of diseases }{ }^{*} \text { or increase in } \\
\text { dosages }\end{array}$} & $34.1 \%$ & $28.6 \%$ & 0.047 & $55.6 \%$ \\
\hline
\end{tabular}

*Hypertension and/or diabetes mellitus and/or hyperlipidemia.

\section{DISCUSSION}

Here we presented the clinical characteristics and prognosis of patients who underwent revascularization therapy in our stroke unit. Patients selected for CAS had a more severe stenosis and higher Rankin scores, though not significant. The risk factors were mostly similar between two groups, except that smoking was more common in CEA group, and hyperlipidemia was more common in CAS group. The followup period was significantly longer in patients with CEA, as the procedure was performed since 1996, while CAS procedure was performed since 2002 . The primary end points in terms of recurrent stroke/TIA, MI and deaths due to cardiovascular complications were similar between two groups. The deaths due to other diseases (such as cancer, accidents...) and other non-fatal complications, however, were significantly more common in CEA patients, while asymptomatic restenosis was significantly more common in CAS group.

In the literature, there are many randomized controlled trials comparing CEA and CAS, though they do not imply how many patients of the stroke population needed revascularization therapy, or the differences in these patients in compared to stroke patients who did not need revascularization. These studies also lack of long-term follow-up, emphasizing the need of more long-term data from stenting versus endarterectomy trials. The first multicenter study was the CAVATAS trial (Carotid and Vertebral Artery Transluminal Angioplasty Study) published in 2001 (31). Here, both symptomatic and asymptomatic patients were enrolled, and the CAVATAS trial demonstrated no statistically significant difference between the surgery arm and the endovascular arm in the rate of stroke or death within 30 days. The 8-year incidence and hazard ratio at the end of followup for ipsilateral non-perioperative stroke was also found insignificant in two groups, though more patients had stroke during follow-up in the endovascular group than in the surgical group (12). The SAPPHIRE (Stenting and Angioplasty With Protection in Patients at High Risk for Endarterectomy) study was the first trial comparing CEA with CAS using distal cerebral protection (22). There were no demographic or baseline medical history differences between the 2 groups, with the majority of patients being asymptomatic (71\%) and approximately $20 \%$ of patients being older than 80 years. The primary end point of the study was death, stoke, and MI. The 30-day stroke/death/MI rate was lower in the CAS group (4.8\%) than in the CEA group, although 
not significant. The CaRESS (Carotid Revascularization Using Endarterectomy or Stenting Systems) trial was designed to prove equivalence between CAS with cerebral protection and CEA in symptomatic and asymptomatic patients (9). Similarly, no statistically significant difference was found between the 30-day and 1-year death and stroke rates. The EVA-3S (Endarterectomy Versus Angioplasty in Patients With Symptomatic Severe Carotid Stenosis) trial was designed to assess the noninferiority of CAS versus CEA in low-risk, symptomatic patients (25). The primary end point was seen in $3.9 \%$ of patients undergoing CEA and $9.6 \%$ of CAS patients $(p<0.01)$, concluding that CAS was inferior to CEA in patients with symptomatic carotid stenosis more than $60 \%$, with respect to the incidence of stroke and death at 30 days postprocedure. A recent CREST (Carotid Revascularization Endarterectomy Versus Stent Trial) and ICSS (International Carotid Stenting Study) trial with a median follow-up period of 2.5 years showed no significant difference in the estimated 4-year rates of the primary end point. However, analysis of the individual components of the composite end point revealed a periprocedural stroke rate of only $2.3 \%$ for CEA and $4.1 \%$ for CAS $(p<0.01)$. Mortality was equivalent in both groups, and $\mathrm{Ml}$ was higher in the surgical group $(\mathrm{p}=0.03)$. For patients $\geq 70$ years old, CAS results were slightly better, with a larger benefit for stenting as the younger the age of the patient. ICSS compared the results of CEA and CAS for patients with only symptomatic carotid stenosis and showed that risks of any stroke and all-cause death were higher in the stenting group. The authors concluded that CEA remains the treatment of choice for patients with symptomatic CS who are suitable for surgery.

A recent meta-analysis of 13 randomized clinical trials showed that CAS was associated with an increased risk of periprocedural outcomes of death, $\mathrm{Ml}$, or stroke, but with reductions in the risk of $\mathrm{Ml}$ and cranial nerve injury when compared with CEA. Another meta-analysis of recent three trials showed that perioperative risk of stroke or death was significantly higher with CAS than with CEA (26). The investigators concluded that CAS for treatment of people with symptomatic carotid artery stenosis should be avoided among people older than 70 years. Data on the safety and potential efficacy of CAS in younger patients were insufficient to draw a conclusion. The currently available periprocedural morbidity/mortality data from several trials have not conclusively shown CAS to be safer than CEA for treatment of either asymptomatic or symptomatic patients. The subsequent risk of ipsilateral stroke appears to be similar with both procedures. However, the long-term durability of CAS has not been established; for example, the rate of recurrent stenosis has not well-established yet. In conclusion, CEA was suggested to remain as the procedure of choice for stroke prevention in patients with severe, symptomatic carotid stenosis (29). CAS was suggested as a good alternative in symptomatic patients with major medical comorbidities precluding CEA. Each patient's risk of MI and stroke should therefore be considered based on a variety of risk factors, and the treatment should be selected only after a comprehensive discussion with the patient.

For proximal vertebral artery reconstruction, early complication rates of $2.5-25 \%$ and perioperative mortality rates of $0-4 \%$ have been reported $(5,6)$. For distal vertebral artery reconstruction, mortality rates have ranged from $2 \%$ to $8 \%$ $(4,19,20,21,36)$. In a review of 300 interventions for proximal vertebral artery stenosis, the risk of death was $0.3 \%$, the risk of periprocedural neurological complications was 5.5\%, and risk of posterior stroke was $0.7 \%$ at a mean follow-up of 14.2 months. Restenosis occurred in $26 \%$ of cases after a mean of 12 months (range 3 to 25 months), although restenosis was not consistently correlated with recurrent symptoms (11). When data from 14 case series were combined, the annual stroke risk after angioplasty for distal vertebrobasilar disease was approximately $3 \%$, and rates of stroke and restenosis appeared to be related to ascending (more distal) location and the anatomic complexity of the offending lesion. The benefit of revascularization versus modern aggressive medical therapy has not been established for patients with vertebral artery stenosis yet, awaiting large, randomized clinical trials with longer follow-up periods.

The large, randomized, controlled trials comparing CEA and CAS are of great importance to improve our understandings for handling stroke patients better. However, they do not imply about our attitudes towards centers performing revascularization therapy, or whether every center treating stroke patients could be able to perform this type of procedures. On this context, EVA 35 study has demonstrated that several technical factors potentially related to the risk of complications following revascularization therapy showed important differences among centers with negative or positive influences on the outcome $(17,25)$. On the other hand, it could be guiding to comprehend our stroke population that needs revascularization therapy and the outcome of our own centers in order to encourage carotid endarterectomy or stenting therapy.

\section{REFERENCES}

1. Adams HP, Bendixen BH, Kappelle LJ, Biller J, Love BB, Gordon $\mathrm{DL}$, Marsh EE 3rd: Classification of subtype of acute ischemic stroke: Definitions for use in a multicenter clinical trial. TOAST. Trial of Org 10172 in Acute Stroke Treatment. Stroke 24: 35-41,1993

2. Adams HP Jr, del Zoppo G, Alberts MJ, Bhatt DL, Brass L, Furlan A, Grubb RL, Higashida RT, Jauch EC, Kidwell C, Lyden PD, Morgenstern LB, Qureshi Al, Rosenwasser RH, Scott PA, Wijdicks EF; American Heart Association; American Stroke Association Stroke Council; Clinical Cardiology Council; Cardiovascular Radiology and Intervention Council; Atherosclerotic Peripheral Vascular Disease and Quality of Care Outcomes in Research Interdisciplinary Working Groups: Guidelines for the early management of adults with ischemic stroke: A guideline from the American Heart Association/American Stroke Association Stroke Council, Clinical Cardiology Council, Cardiovascular Radiology and 
Intervention Council, and the Atherosclerotic Peripheral Vascular Disease and Quality of Care Outcomes in Research Interdisciplinary Working Groups: The American Academy of Neurology affirms the value of this guideline as an educational tool for neurologists. Stroke 38: 1655-1711,2007

3. Barnett HJ, Gunton RW, Eliasziw M, Fleming L, Sharpe B, Gates P, Meldrum H: Causes and severity of ischemic stroke in patients with internal carotid artery stenosis. JAMA 283: 1429-1436, 2000

4. Berguer R, Flynn LM, Kline RA, Caplan L: Surgical reconstruction of the extracranial vertebral artery: Management and outcome. J Vasc Surg 31: 9-18,2000

5. Berguer R, Morasch MD, Kline RA: A review of 100 consecutive reconstructions of the distal vertebral artery for embolic and hemodynamic disease. J Vasc Surg 27: 852859,1998

6. Berguer R: Suboccipital approach to the distal vertebral artery. J Vasc Surg 30: 344-349,1999

7. Biller J, Feinberg WM, Castaldo JE, Whittemore AD, Harbaugh RE, Dempsey RJ, Caplan LR, Kresowik TF, Matchar DB, Toole JF, Easton JD, Adams HP Jr, Brass LM, Hobson RW 2nd, Brott TG, Sternau L: Guidelines for carotid endarterectomy: A statement for healthcare professionals from a Special Writing Group of the Stroke Council, American Heart Association. Circulation 97: 501-509, 1998

8. Biller J, Feinberg WM, Castaldo JE, Whittemore AD, Harbaugh RE, Dempsey RJ, Caplan LR, Kresowik TF, Matchar DB, Toole J, Easton JD, Adams HP Jr, Brass LM, Hobson RW 2nd, Brott TG, Sternau L: Guidelines for carotid endarterectomy: a statement for healthcare professionals from a special writing group of the Stroke Council, American Heart Association. Stroke 29: 554-562,1998

9. CARESS Steering Committee: Carotid revascularization using endarterectomy or stenting systems (CARESS): Phase I clinical trial. J Endovasc Ther 10: 1021-1030, 2003

10. Chaturvedi S, Bruno A, Feasby T, Holloway R, Benavente O, Cohen SN, Cote R, Hess D, Saver J, Spence JD, Stern B, Wilterdink J; Therapeutics and Technology Assessment Subcommittee of the American Academy of Neurology: Carotid endarterectomy-an evidence-based review: Report of the Therapeutics and Technology Assessment Subcommittee of the American Academy of Neurology. Neurology 65:794-801, 2005

11. Eberhardt O, Naegele T, Raygrotzki S, Weller M, Ernemann $\mathrm{U}$ : Stenting of vertebrobasilar arteries in symptomatic atherosclerotic disease and acute occlusion: Case series and review of the literature. J Vasc Surg 43: 1145-1154,2006

12. Ederle J, Bonati LH, Dobson J, Featherstone RL, Gaines PA, Beard JD, Venables GS, Markus HS, Clifton A, Sandercock P, Brown MM; CAVATAS Investigators: Endovascular treatment with angioplasty or stenting versus endarterectomy in patients with carotid artery stenosis in the Carotid and Vertebral Artery Transluminal Angioplasty Study (CAVATAS): Long-term follow-up of a randomised trial. Lancet 8: 898-907,2009
13. European Stroke Organisation (ESO) Executive Committee; ESO Writing Committee: Guidelines for management of ischaemic stroke and transient ischaemic attack 2008. Cerebrovasc Dis 25: 457-507, 2008

14. Fine-Edelstein JS, Wolf PA, O'Leary DH, Poehlman $\mathrm{H}$, Belanger AJ, Kase CS, D'Agostino RB: Precursors of extracranial carotid atherosclerosis in the Framingham Study. Neurology 44: 1046-1050, 1994

15. Goldstein LB, Adams R, Becker K, Furberg CD, Gorelick PB, Hademenos G, Hill M, Howard G, Howard VJ, Jacobs B, Levine SR, Mosca L, Sacco RL, Sherman DG, Wolf PA, del Zoppo GJ: Primary prevention of ischemic stroke: A statement for healthcare professionals from the Stroke Council of the American Heart Association. Circulation 103: 163-182, 2001

16. Goldstein LB, Adams R, Alberts MJ, Appel LJ, Brass LM, Bushnell CD, Culebras A, DeGraba TJ, Gorelick PB, Guyton JR, Hart RG, Howard G, Kelly-Hayes M, Nixon JV, Sacco RL; American Heart Association; American Stroke Association Stroke Council: Primary prevention of ischemic stroke: A guideline from the American Heart Association/American Stroke Association Stroke Council: Cosponsored by the Atherosclerotic Peripheral Vascular Disease Interdisciplinary Working Group; Cardiovascular Nursing Council; Clinical Cardiology Council; Nutrition, Physical Activity, and Metabolism Council; and the Quality of Care and Outcomes Research Interdisciplinary Working Group. Circulation 113: 873-923, 2006

17. Harjai KJ, Mehta RH: Trials and tribulations of carotid artery stenting. J Interven Cardiol 20: 389-394, 2007

18. Helton TJ, Bavry AA, Rajagopal V, Anderson RD, Yadav JS, Bhatt DL: The optimal treatment of carotid atherosclerosis: A 2008 update and literature review. Postgrad Med 120: 103-112, 2008

19. Hopkins LN, Budny JL, Castellani D: Extracranial-intracranial arterial bypass and basilar artery ligation in the treatment of giant basilar artery aneurysms. Neurosurgery 13:189-194, 1983

20. Hopkins LN, Budny JL, Spetzler RF: Revascularization of the rostral brain stem. Neurosurgery 10: 364-369, 1982

21. Hopkins LN, Martin NA, Hadley MN, Spetzler RF, Budny J, Carter LP: Vertebrobasilar insufficiency: part 2: microsurgical treatment of intracranial vertebrobasilar disease. J Neurosurg 66: 662-674, 1987

22. Kastrup A, Gröschel K, Krapf H, Brehm BR, Dichgans J, Schulz JB: Early outcome of carotid angioplasty and stenting with and without cerebral protection devices: A systematic review of the literature. Stroke 34: 813-819, 2003

23. Liapis CD, Bell PR, Mikhailidis D, Sivenius J, Nicolaides A, Fernandes e Fernandes J, Biasi G, Norgren L; ESVS Guidelines Collaborators: ESVS guidelines: Invasive treatment for carotid stenosis: Indications, techniques. Eur J Vasc Endovasc Surg 37: $1-19,2009$ 
24. Lloyd-Jones D, Adams R, Carnethon M, De Simone G, Ferguson TB, Flegal K, Ford E, Furie K, Go A, Greenlund K, Haase N, Hailpern S, Ho M, Howard V, Kissela B, Kittner S, Lackland D, Lisabeth L, Marelli A, McDermott M, Meigs J, Mozaffarian D, Nichol G, O'Donnell C, Roger V, Rosamond W, Sacco R, Sorlie P, Stafford R, Steinberger J, Thom T, Wasserthiel-Smoller S, Wong N, Wylie-Rosett J, Hong Y; American Heart Association Statistics Committee and Stroke Statistics Subcommittee: Heart disease and stroke statistics--2009 update: A report from the American Heart Association Statistics Committee and Stroke Statistics Subcommittee. Circulation 119: e21-181, 2009

25. Mas JL, Chatellier G, Beyssen B, Branchereau A, Moulin T, Becquemin JP, Larrue $V$, Lièvre $M$, Leys $D$, Bonneville JF, Watelet J, Pruvo JP, Albucher JF, Viguier A, Piquet $P$, Garnier $P$, Viader $F$, Touzé $E$, Giroud $M$, Hosseini $H$, Pillet JC, Favrole $P$, Neau JP, Ducrocq X; EVA-3S Investigators: Endarterectomy versus stenting in patients with symptomatic severe carotid stenosis. N Engl J Med 355: 1660-1671, 2006

26. Mayberg MR, Wilson SE, Yatsu F, Weiss DG, Messina L, Hershey LA, Colling C, Eskridge J, Deykin D, Winn HR; Veterans Affairs Cooperative Studies Program 309 Trialist Group: Carotid endarterectomy and prevention of cerebral ischemia in symptomatic carotid stenosis. JAMA 266: 3289-3294, 1991

27. Moore WS, Barnett HJ, Beebe HG, Bernstein EF, Brener BJ, Brott T, Caplan LR, Day A, Goldstone J, Hobson RW 2nd, et al.: Guidelines for carotid endarterectomy. A multidisciplinary consensus statement from the ad hoc Committee, American Heart Association. Stroke 26: 188-201, 1995

28. North American Symptomatic Carotid Endarterectomy Trial Collaborators: Beneficial effect of carotid endarterectomy in symptomatic patients with high-grade carotid stenosis. $\mathrm{N}$ Engl J Med 325: 445-453,1991

29. Pandian JD: Recent concepts in the management of extracranial carotid stenosis: carotid endarterectomy versus carotid artery stenting. Neurol India 59: 376-382, 2011
30. Prevalence of disabilities and associated health conditions among adults-United States, 1999. MMWR Morb Mortal Wkly Rep 50: 120-125, 2001

31. Protack CD, Bakken AM, Saad WE, Illig KA, Waldman DL, Davies MG: Radiation arteritis: A contraindication to carotid stenting? J Vasc Surg 45: 110-117, 2007

32. Randomised trial of endarterectomy for recently symptomatic carotid stenosis: final results of the MRC European Carotid Surgery Trial (ECST). Lancet 351: 1379-1387, 1998

33. Ricotta JJ 2nd, Piazza M: Carotid endarterectomy or carotid artery stenting? Matching the patient to the intervention. Perspect Vasc Surg Endovasc Ther 22: 124-136, 2010

34. Rothwell PM, Eliasziw M, Gutnikov SA, Fox AJ, Taylor DW, Mayberg MR, Warlow CP, Barnett HJ; Carotid Endarterectomy Trialists' Collaboration: Analysis of pooled data from the randomised controlled trials of endarterectomy for symptomatic carotid stenosis. Lancet 361: 107-116, 2003

35. Sacco RL, Adams R, Albers G, Alberts MJ, Benavente O, Furie K, Goldstein LB, Gorelick P, Halperin J, Harbaugh R, Johnston SC, Katzan I, Kelly-Hayes M, Kenton EJ, Marks M, Schwamm LH, Tomsick T; American Heart Association; American Stroke Association Council on Stroke; Council on Cardiovascular Radiology and Intervention; American Academy of Neurology: Guidelines for prevention of stroke in patients with ischemic stroke or transient ischemic attack: a statement for healthcare professionals from the American Heart Association/American Stroke Association Council on Stroke: co-sponsored by the Council on Cardiovascular Radiology and Intervention: The American Academy of Neurology affirms the value of this guideline. Stroke 37: 577-617, 2006

36. Spetzler RF, Hadley MN, Martin NA, Hopkins LN, Carter LP, Budny J: Vertebrobasilar insufficiency: part 1: microsurgical treatment of extracranial vertebrobasilar disease. J Neurosurg 66: 648-661, 1987 